\title{
Concentration Optimization $\mathrm{Na}_{2} \mathrm{CO}_{3}$ Alginates from Turbinaria sp. As Raw Material Electrolyte Polymer
}

\section{Optimasi Konsentrasi Alginat $\mathrm{Na}_{2} \mathrm{CO}_{3}$ dari Turbinaria sp. Sebagai Bahan Baku Polimer Elektrolit}

\author{
Dinda Liyana, Nurhadini, dan Ristika Oktavia Asriza* \\ Department of Chemistry, Universitas of Bangka Belitung \\ Kampus Terpadu Universitas Bangka Belitung, Bangka, Bangka Belitung, 33172 \\ *Corresponding author: ristika@ubb.ac.id
}

\begin{abstract}
ABSTRAK
Polimer elektrolit berfungsi sebagai media transpor elektron dan sebagai pemisah antara anoda dan katoda. Polimer elektrolit dapat disintesis dari rumput laut coklat Turbinaria sp. Namun optimasi ekstraksi alginat belum banyak dilakukan, sehingga penelitian ini bertujuan untuk mengetahui kondisi optimum variasi konsentrasi $\mathrm{Na}_{2} \mathrm{CO}_{3}(3 \%, 5 \%, 7 \%)$ pada ekstrak Turbinaria sp sebagai bahan baku. bahan untuk sintesis elektrolit polimer untuk DSSC. Hasil ekstraksi alginat optimum diketahui persentase rendemen, kadar air dan gugus fungsi menggunakan analisis FTIR. Kondisi optimum ekstraksi alginat dari Turbinaria sp adalah $\mathrm{Na}_{2} \mathrm{CO}_{3} 5 \%$ dan suhu $60{ }^{\circ} \mathrm{C}$ dengan rendemen $23,81 \%$ dan kadar air $8,1 \%$. Hasil FTIR juga menunjukkan intensitas manuronik terkuat terlihat pada bilangan gelombang $822 \mathrm{~cm}^{-1}$.
\end{abstract}

Kata Kunci: Alginat, $\mathrm{Na}_{2} \mathrm{CO}_{3}$, polimer elektrolit

\section{PENDAHULUAN}

Pemakaian energi listrik di berbagai bidang terus mengalami peningkatan. Jika ketersedian energi listrik tidak dikelola dengan baik maka akan mengakibatkan krisis energi listrik. Oleh karena itu dilakukan upaya untuk berinovasi dan mencari sumber-sumber energi alternatif (Alhuja dan Tatsutani, 2009). Salah satu sumber alternatif terbesar yang dapat dimanfaatkan yaitu berasal dari energi matahari (solar cell). Energi matahari yang mencapai permukaan bumi berkisar 10.000 TW. Salah satu aplikasi dari pemanfaatan energi matahari adalah Dye Sensitized Solar Cell (DSSC).

DSSC tersusun atas semikonduktor, elektroda pembanding, zat warna (dye), dan polimer elektrolit. Polimer elektrolit merupakan elektrolit padat yang berfungsi sebagai media dalam penghantar elektron. Syarat suatu material yang dapat dijadikan sebagai polimer elektrolit adalah mempunyai kekuatan mekanik yang tinggi, konduktivitas yang tinggi, mudah dibuat dalam ukuran yang tipis, dan mempunyai kestabilan termal yang tinggi (Marfuatun, 2011).

Akhir-akhir ini sintesis polimer elektrolit banyak berasal dari alam karena memiliki keunggulan yaitu mudah didapat, murah, keberadaannya melimpah dialam dan mudah didegradasi (Rudziah, 2016). Adapun beberapa sumber dari polimer elektrolit tersebut adalah selulosa, kitosan, karagenan dan alginat (Buraidah dkk., 2010; Bella dkk., 2015; Herdianto, 2019; Nurhadini dkk., 2019). 
Alginat merupakan senyawa polimer alam yang berasal dari turunan polisakarida. Alginat mempunyai kekuatan mekanik yang tinggi, dimana nilai kekuatan tariknya sebesar 21,18 Mpa, memiliki ketebalan $140 \mu \mathrm{m}$ (Wafiroh, 2016).

Alginat dapat diperoleh dari ekstraksi pada jaringan sel rumput laut antara lain Turbinaria dan Sargassum. Berdasarkan kajian literatur mengenai ekstraksi alginat dari rumput laut. Wibowo dkk. (2013) melaporkan bahwa suhu $50^{\circ} \mathrm{C}$ dengan konsentrasi $\mathrm{Na}_{2} \mathrm{CO}_{3} 7 \%$ adalah kondisi terbaik untuk mengekstrak rumput laut Turbinaria sp dengan rendemen alginat yang dihasilkan sebesar $21,43 \%$. Namun penelitian ekstraksi mutu alginat dari Turbinaria sp sebagai polimer tidak banyak dilakukan. Oleh karena itu, dilakukan penelitian tentang optimasi konsentrasi $\mathrm{Na}_{2} \mathrm{CO}_{3}$ agar diperoleh rendemen yang optimum sebagai bahan baku sintesis polimer elektrolit.

\section{METODOLOGI}

\section{Bahan}

Rumput laut cokelat Turbinaria sp, Akuades, Natrium hidroksida $(\mathrm{NaOH})$ Merck, Natrium karbonat $\left(\mathrm{Na}_{2} \mathrm{CO}_{3}\right)$ Merck, Asam sulfat $\left(\mathrm{H}_{2} \mathrm{SO}_{4}\right)$ Merck, Peroksida $\left(\mathrm{H}_{2} \mathrm{O}_{2}\right)$ Merck, dan Isopropil Alkohol teknis

\section{Alat}

Berikut alat-alat yang digunakan dalam penelitian ini adalah: Seperangkat alat gelas seperti; Gelas beaker 100, 250, dan $1000 \mathrm{~mL}$, gelas labu leher $1000 \mathrm{~mL}$, gelas ukur $5 \mathrm{~mL}$ dan $100 \mathrm{~mL}$, Stirrer, Hotplate, Neraca analitik, plat/wadah kaca, labu leher 2, Termometer, Cawan petri, Alumunium foil, Plastik wrapping,

\section{Prosedur \\ Ekstraksi alginat pada Turbinaria sp.}

Rumput laut cokelat jenis Turbinaria sp yang berasal dari Pantai Tuing Kepulauan Bangka dibersihkan dan dikeringkan.Selanjutnya, rumput laut yang telah kering tersebut diblender sampai halus. Sebanyak 30 gram rumput laut direndam selama 1 jam dalam larutan $\mathrm{H}_{2} \mathrm{SO}_{4} 2 \%$ dengan perbandingan 1:20 (w/v). Kemudian rumput laut tersebut dinetralkan dengan akuadest sampai $\mathrm{pH}=$ 6-7 Selanjutnya rumput laut cokelat tersebut direndam dengan $\mathrm{NaOH} 0,5 \%$ selama 30 menit dan dinetralkan dengan akuadest sampai pH 7. Endapan sampel tersebut dipanaskan dengan larutan $\mathrm{Na}_{2} \mathrm{CO}_{3}$ pada variasi $\mathrm{Na}_{2} \mathrm{CO}_{3} 3 \%, 5 \%, 7 \%$ dengan perbandingan rumput laut cokelat dan larutan $\mathrm{Na}_{2} \mathrm{CO}_{3}$ adalah 1:20 (w/v) selama 2 jam suhu $60^{\circ} \mathrm{C}$. Hasil ekstrak disentrifugasi pada 4500 rpm dan filtrat ditambahkan larutan $\mathrm{H}_{2} \mathrm{O}_{2} 10 \%$ sampai larutan bewarna kuning. Kemudian larutan tersebut ditambahkan dengan larutan $\mathrm{H}_{2} \mathrm{SO}_{4} \quad 10 \%$ dan dibiarkan selama 30 menit sampai $\mathrm{pH}=1-2$ dan akan terbentuk serat.

Endapan tersebut merupakan gel asam alginat. Kemudian gel asam alginat dilarutkan dalam $\mathrm{NaOH} 10 \%$ hingga homogen dan ber-pH netral. Sedikit demi sedikit larutan tersebut dituangkan kedalam larutan isopropil alkohol perlahan sambil diaduk. Kemudian serat natrium alginat akan terbentuk setelah didiamkan selama 30 menit. Larutan disentrifuge sehingga didapatkan serat natrium alginat. Serat natrium alginat yang terbentuk dikeringkan sehingga terbentuk bubuk natrium alginat (Mahbub, 2012; Jayanudin dkk., 2014). Serat alginat yang diperoleh dikarakterisasi dengan FTIR dan dihitung rendemen serta kadar airnya untuk menentukan kondisi optimum.

\section{HASIL DAN PEMBAHASAN}

\section{Pengaruh konsentrasi $\mathrm{Na}_{2} \mathrm{CO}_{3}$ terhadap hasil rendemen natrium alginat}

Dari gambar 1 menunjukkan bahwa pada penambahan $\mathrm{Na}_{2} \mathrm{CO}_{3} 3 \%$ akan menghasilkan rendemen sebesar $21,31 \%$. Pada konsentrasi $\mathrm{Na}_{2} \mathrm{CO}_{3} 5 \%$ memperoleh rendemen natrium alginat tertinggi yaitu $23,81 \%$. Sedangkan pada konsentrasi $\quad \mathrm{Na}_{2} \mathrm{CO}_{3} \quad 7 \%$ menghasilkan rendemen natrium alginat 20,49\%. Berdasarkan pada Gambar 1 penambahan $\mathrm{Na}_{2} \mathrm{CO}_{3} 7 \%$ terjadi penurunan dari rendemen natrium alginat yang disebabkan natrium alginat terdegradasi dengan ditandai hilangnya jejak serapan manurorat yang merupakan ciri khas dari natrium alginat pada analisis FTIR.

Hasil penelitian ini bersesuian dengan penelitian Prasetyaningrum (2002) yang telah dilakukan menggunakan $\mathrm{Na}_{2} \mathrm{CO}_{3} \quad 1-7 \%$. Konsentrasi $\mathrm{Na}_{2} \mathrm{CO}_{3}$ dalam proses ekstraksi alginat sangat berpengaruh terhadap rendemen yang dihasilkan. Pada konsentrasi 1$5 \%$ mengalami kenaikan jumlah natrium alginat dengan konsentrasi optimum pada $\mathrm{Na}_{2} \mathrm{CO}_{3}$ 5\%. Kemudian untuk konsentrasi $\mathrm{Na}_{2} \mathrm{CO}_{3} 6 \%$ dan $7 \%$ jumlah rendemen yang di 
dapatkan mengalami penurunan. Disebabkan terciptanya suasana basa pada larutan, sehingga natrium alginat terdegradasi.

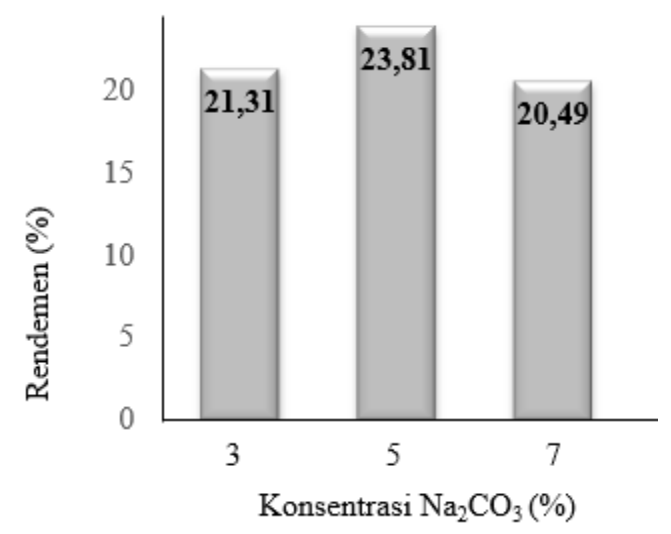

Gambar 1. Rendemen Natrium Alginat Dengan Variasi $\mathrm{Na}_{2} \mathrm{CO}_{3}$

\section{Pengaruh kadar air terhadap variasi $\mathrm{Na}_{2} \mathrm{CO}_{3}$}

Fungsi pengukuran kadar air adalah untuk mengetahui berat kering dari alginat yang dihasilkan. Karena kadar air juga dapat menentukan kualitas dan daya tahan dari alginat. Jika alginat mengadung kadar air yang tinggi maka akan menyebabkan kerusakan pada alginat akibat adanya reaksi kimiawi maupun pertumbuhan mikroba pembusuk.

Tabel 1. Kadar Air Natrium Alginat variasi $\mathrm{Na}_{2} \mathrm{CO}_{3}$

\begin{tabular}{cc}
\hline $\begin{array}{c}\text { Konsentrasi } \\
\mathrm{Na}_{2} \mathrm{CO}_{3}(\%)\end{array}$ & $\begin{array}{l}\text { Kadar } \\
\text { air } \\
\text { (\%) }\end{array}$ \\
\hline 3 & 10 \\
5 & 8,1 \\
7 & 9,5 \\
\hline
\end{tabular}

Hasil analisis pada tabel di atas menunjukkan bahwa pada konsentrasi $\mathrm{Na}_{2} \mathrm{CO}_{3}$ $3 \%$ kadar air yang didapat $10 \%$. Pada konsentrasi $\mathrm{Na}_{2} \mathrm{CO}_{3} 5 \%$ merupakan kadar air terendah yaitu $8,1 \%$. Sedangkan pada konsentrasi $\mathrm{Na}_{2} \mathrm{CO}_{3} 7 \%$ kadar airnya adalah 9,5\%. Perbedaan kadar air dapat disebabkan oleh faktor penyimpanan natrium alginat. Menurut Winarno (1990) besaran kadar air yang diperbolehkan dalam natrium alginat berkisar 5-20\%. Pada penelitian ini kadar air yang didapatkan memenuhi standar.

\section{Analisis Gugus Fungsi Natrium Alginat} Terhadap variasi $\mathrm{Na}_{2} \mathrm{CO}_{3}$

Dari spektrum tersebur terlihat bahwa terdapat puncak spektrum pada bilangan gelombang rentang $3200-3500 \mathrm{~cm}^{-1}$ puncak ini menunjukan gugus hidroksil $(\mathrm{O}-\mathrm{H})$ pada bilangan gelombang $3267 \mathrm{~cm}^{-1}, 3460 \mathrm{~cm}^{-1}$, dan $3628 \mathrm{~cm}^{-1}$. Gugus spektrum terdapat $\mathrm{COO}^{-}$ asimetris rentang bilangan gelombangnya 1600-1680 $\mathrm{cm}^{-1}$. Pada spektrum di atas ditunjukan pada daerah serapan $1602 \mathrm{~cm}^{-1}$, $1692 \mathrm{~cm}^{-1}$, dan $1611 \mathrm{~cm}^{-1}$. Pada gugus COO simetris bilangan gelombang berada disekitaran $1410 \mathrm{~cm}^{-1}$, pada hasil spekrumnya berada dibilangan gelombang $1434 \mathrm{~cm}^{-1}, 1451$ $\mathrm{cm}^{-1}$ dan $1452 \mathrm{~cm}^{-1}$. Kemudian sidik jari khas guluronat ditunjukkan pada daerah serapan 890-900 $\mathrm{cm}^{-1}$ dan jejak serapan manurorat terdapat pada daerah serapan $810-850 \mathrm{~cm}^{-1}$ pada $\mathrm{Na}_{2} \mathrm{CO}_{3} 3 \%$ yang menandakan manurorat dengan intensitas lemah. Dan pada $\mathrm{Na}_{2} \mathrm{CO}_{3} 5 \%$ terdeteksi bilangan gelombang $822 \mathrm{~cm}^{-1}$ dengan intensitas terkuat yang ditandai adanya serapan gugus manurorat. Sedangkan $\mathrm{Na}_{2} \mathrm{CO}_{3}$ $7 \%$ tidak terdeteksi serapan manurorat karena telah mengalami degradasi.

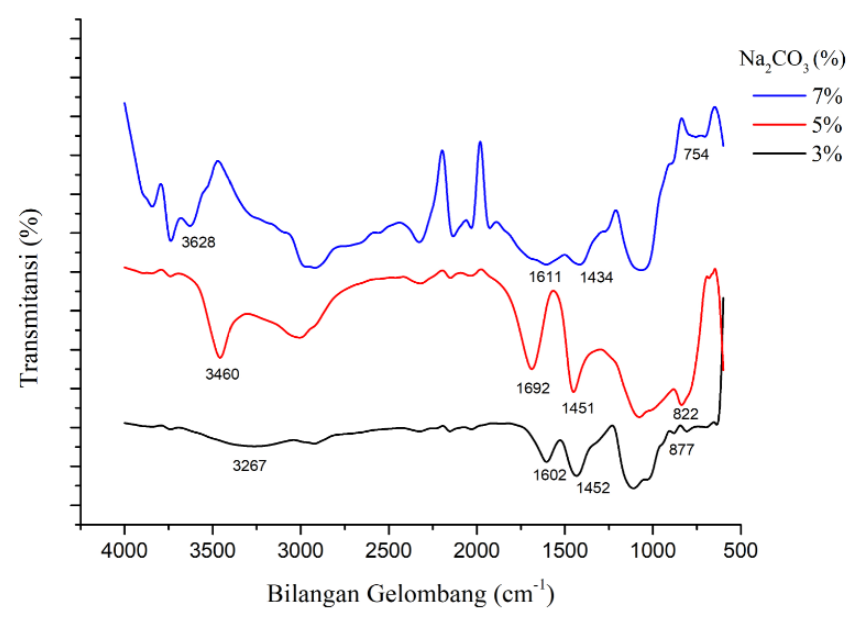

Gambar 2. Spektrum FTIR Natrium Alginat Terhadap Variasi $\mathrm{Na}_{2} \mathrm{CO}_{3}$

\section{KESIMPULAN}

Kondisi optimum ekstraksi natrium alginat didapatkan dari Turbinaria sp pada konsentrasi $\mathrm{Na}_{2} \mathrm{CO}_{3} \quad 5 \%$ pada suhu $60^{\circ} \mathrm{C}$ dilakukan dengan analisis yang menghasilkan rendemen $23,81 \%$ dan kadar air 8,1\%. Analisis FTIR menunjukan intensitas manuronat terkuat terlihat pada bilangan gelombang 822 $\mathrm{cm}^{-1}$. Natrium alginat hasil ekstraksi dapat dijadikan sebagai bahan baku dalam sintesis polimer elektrolit. 


\section{UCAPAN TERIMA KASIH}

Ucapan terima kasih kepada Universitas Bangka Belitung melalui program PDTU.

\section{REFERENSI}

Ahuja, D,. Tatsutani. (2009). Sustainable Energy for Developing Countries. Survey and Perspectives integrating environment dan society, 2(1).

Bella, F., Mobarak, N.N., Jumaah, F.N., Ahmad, A. (2015). From Seaweeds to Biopolymeric electrolytes for Third Generation Solar Cells: An intriguing approach. Electrochim, 151, 306-311.

Buraidah, M.H., Teo, L.P., Majid, S.R., Yahya, R., Taha, R.M., Arof, A.K. (2010). Characterizations of chitosan-based polymer electrolyte photovoltaiccells. Int. J. Photoenergy, 1-7.

Herdianto, R.W., Husni A. (2019). Optimasi suhu ekstraksi terhadap kualitas alginat yang diperoleh dari rumput laut Sargassum muticum. Jurnal Pengolahan Hasil Perikanan Indonesia, 22(1): 164173.

Marfuatun. (2011). Membran Elektrolit Untuk Aplikasi Baterai Ion Litium. Prosiding Seminar Nasional Penelitian, Pendidikan dan Penerapan MIPA, Fakultas MIPA, Universitas Negeri Yogyakarta, [14 Mei 2011]

Nurhadini., Asriza, R.O., Anggraeni., Setiawan, Yudi. (2019). Sodium Alginate extraction from brown seaweed (Turbinaria conoides) and its structural property as biopolymer electrolyte. Proceedings of the International Conference on Maritime and Archipelago. Atlantis Press, 167. 170-172.

Prasetyaningrum, A., dan Purbasari, A. (2002). Ekstraksi Alginat Dari Rumput Laut Dan Aplikasinya Pada Industri. Universitas Diponegoro. Semarang. Reaktor. 6(2), 6367

Pujiarti, H. (2014). Kajian Karakteristik Fotovoltaik dan Impedensi dari Dye Sensitized Solar Cell (DSSC) dengan Gel Elektrolit. Tesis. Departemen Fisika. Fakultas Matematika dan Ilmu

Pengetahuan Alam. Institut Teknologi Bandung: Bandung.

Rudhziah, S., Ahmad, A., Ishak, A., Mohamed, N.S. (2015). Biopolymer electrolytes based on blend of kappa-carrageenan and cellulose derivatives for potential application in DSSC. Electrochim. Acta, 72, 133-141

Wafiroh, S., Suyanto, Yuliana. (2016). Pembuatan Dan Karakterisasi Membran Komposit Kitosan-Sodium Alginat Terfosforilasi Sebagai Proton Exchange Membrane Fuel Cell (PEMFC), Jurnal Kimia Riset, 1(1), 14-21.

Wibowo, A, Ridlo A, Sedjati S. (2013). Pengaruh suhu ekstraksi terhadap kualitas alginat rumput laut Turbinaria sp. dari pantai Krakal, Gunung Kidul, Yogyakarta. Journal of Marine Research, 2(3), 15-24.

Winarno, F.G. (1996). Teknologi Pengolahan Rumput Laut. P.T. Gramedia Pustaka Utama, Jakarta, 